\title{
Classroom Reform Movement: A New Perspective of Teaching Reform on Ideological and Political Course in Colleges and Universities*
}

\author{
Lidan Ma \\ College of Marxism \\ Heihe University \\ Heihe, China 164300
}

\begin{abstract}
The rising classroom reform movement provides a new perspective for the reform of ideological and political education in universities. The classroom reform is an inevitable product of education informatization, a logical development of the reform of small-class teaching, a trend that combines the needs of teaching reforms such as the collaborative applications of big data information resources, small-class discussion, microlecture, case teaching, and so on. It is of great significance for political theory courses teaching in colleges and universities to enter the era of education informatization 2.0.
\end{abstract}

Keywords-classroom reform movement; ideological and political education in colleges and universities; teaching reform

\section{INTRODUCTION}

Since the "Horizon Report" put forward the "Restructuring of Learning Space," some universities in the world have quietly emerged a classroom reform movement. Based on the diverse learning space such as project cooperation, team presentation, self-learning, free discussion, leisurely relaxation, engineering design and so on, the learning space design is moving from the concept to the reality. "The learning space (environment) problem has received more and more attention. Especially serving as a starting point for school education reform, it has begun to attract the attention of more and more countries, local governments, and schools at all levels. "[1] Integrated with advanced information technology, scientific development of teaching ideas, the change of learning space puts forward higher requirements for school management, teachers' teaching and student learning, and meanwhile it is an important starting point for school education reform. Although the reform of ideological and political education in universities has continued for many years, the situation of "one hundred students learning in one classroom" in many schools has not yet been broken, and "phubber" are very common. The classroom reform movement not only

*Fund Project: Higher education teaching reform project in Heilongjiang province in 2017: The Ideological and Political Theory Course, Research on thematic teaching reform of "Four into four beliefs"- "Study on Collaborative Application of Micro-course and Case Teaching in Ideological and Political Theory Course" (Project Number: SJGSZD2017002) provided a new teaching place for the reform of ideological and political education in universities, but also a new reform perspective for teaching reform.

\section{THE RISE OF THE ClASSROOM REFORM MOVEMENT}

Beijing Normal University is the earliest university in China to conduct pilot reforming classrooms. In 2014, a pilot project was conducted on the 7th floor of teaching building. In April 2015, a language lab on the second floor of the fourth teaching building was transformed into classrooms for small-class discussion. It owned a ring screen that could display PPT, web pages, and students' homework at the same time. Teachers and students can use tablet computers to complete questions and answers and other teaching process Since 2016, Tsinghua University, Peking University, China Agricultural University, Central China Normal University, Fuzhou University and other top universities in China have successively carried out classroom reforms. In addition to transforming into seminar rooms, the most basic change, and more information technologies have been integrated to embody the design concept of integrated cloud diversification mode, visual behavior, mobile devices, intelligent control, and green energy consumption as well as present the actual results of "high-end, elegant, and highlevel". Foreign colleges and universities always have discussion classrooms and most of them adopt take casebased and seminar-style teaching. Based on the previous discussion classrooms, the concept of scientific development of reconstructing learning spaces was incorporated, more advanced information technology and applications were added, and the use of technology to support students' active learning was highlighted. Massachusetts Institute of Technology has built TEAL Classroom (Technology Enabled Active Learning). The classroom has eight viewing screens and the walls are whiteboards that can be written. When the group discusses, students can write formulas and their own ideas freely. The outstanding features of the active learning classroom at the University of Maryland are those tables and chairs are round, and they can "force" students to meet "face-to-face" and concentrate on the classroom fully. The classroom reform movement is not an attempt by several universities to simply conduct education informatization, but 
a new trend in the field of education reform movement and an inevitable choice for the realization of education informatization in the new era of the Internet of Everything + Artificial Intelligence.

\section{THE ESSENCE OF ClassRoOM REFORM MOVEMENT}

The rise of classroom reform is not an accidental phenomenon but an inevitable trend. It not only represents the upgrading of education informatization thinking, but also shows the renewal of university teaching reform cognition and broad vision.

\section{A. The Classroom Reform Movement Is an Inevitable Product of Education Informatization}

Today, with the development of the information technology revolution, mankind has already bid farewell to the agricultural era and the industrial age, entering the new era of interconnectivity + artificial intelligence with integration as the basic feature. Educational field is unavoidably involved in a wave of change. The Party Central Committee and the State Council attach great importance to the issue of China's education informatization. At present, China's educational informatization projects and focus have achieved remarkable results, and formed a systematic education policy system and strategic deployment. It built a security system of education information organization in China giving play to China's institutional advantages, formed a working attitude of taking "three links and two platforms" as the core, and explored a development path of education informatization with Chinese characteristics. [2] "From the beginning of the 19th National Party Congress, education informatization in China has entered a new era of integrated innovation and intelligence--the era of education informatization 2.0". [3] Changes in the teaching environment and the upgrading of educational scenes will surely become the mainstream trend of education reform.

The sadly arisen classroom reform movement is a practice that conforms to the development trend of education informatization and education scenes upgrade. First is the upgrade of student desks and chairs. The fixed long tables and chairs are upgraded to mobile round tables and chairs, which can transform the layout according to classroom needs, and create a scene and route of activities to condense students' body and mind fully as well as help teachers communicate with students in a natural state. Second is upgrade of multimedia Equipment. The square screen has been upgraded to a super-wide screen or polyhedral screen, giving students a experience feeling of "viewing level" and further bringing about a psychological transformation. Finally is the upgrade of overall classroom environment. The impact of the environment on people does not need to be elaborated. The upgrading of overall classroom environment that integrates technological factors is not only conducive to students' learning with physical and mental pleasure, but helpful for teachers' dedication to teaching.

\section{B. The Pushing Force behind the Classroom Reform Movement Is the Reform of Small-class Teaching}

Small-class teaching is a trend of teaching reforms in countries all over the world. It is a change in the classroom style from "teaching primarily" to "learning primarily". The modern teaching model generally emphasizes "learningcentered", and it uses heuristic, inquiry-based and discussion-based teaching to gradually replace instilling teaching model. Just imagine, there are hundreds of people sitting in a large classroom and being crowded. How can teachers and students conduct effective discussions face-toface? In order to truly realize the reform of the "learningcentered" teaching model, it is necessary to eliminate large classes. At the NPC\&CPPCC in 2018, the Minister of Education gave a clear timetable for the elimination of large classes in primary and secondary schools. By 2018, the large class of more than 66 people will be basically eliminated, and the large class of 56 people will be basically eliminated in 2020. Similarly, small-class seminar is also a new trend of educational reform in colleges and universities. [4] In the class of "Lectures of one hundred people", which is mainly taught by teachers, students are often passively accepted as the role of educational objects. With the help of educational information technology, students' enthusiasm is mobilized in the new classroom. Giving full play to the initiative of students in the new classroom of independent learning and collaborative learning can enable students to turn from education objects to subjects truly. Xie Heping, president of Sichuan University, pointed out: "To cultivate students' critical thinking requires us to change from traditional indoctrination education to heuristic teaching, critical discussion, and non-standard answer-based examinations. To build an elite-educated college requires 'small-class' classroom". [5]

Space is magical. As the core proposition of the new teaching reform, small-class teaching conforms to the trend of the times and meets reasonable requirements of the state for the realization of education modernization. It is the trend of the times and what people want. Facts have proved that the information seminar classroom after the transformation win warm praise from teachers and students. The changes in the space environment have rewritten the traditional classroom model based on knowledge transfer, so that each student can participate in interactive discussions. It fully attracts students' attention, extensively mobilizes the enthusiasm of students, and has played an unprecedented role in the teaching reform from "knowledge imparting" to "ability cultivation" revolution. Using education technology to create an effective learning environment and learning resources, with questions as guidance to strengthen students' intrinsic learning motivation and driving force of selfmanagement, and using dialogues and exchanges to help teachers and students achieve the "free switch" of roles, the teaching reform make learning become a kind of efficient and beautiful emotional experience. 


\section{THE Classroom ReForm MOVEMENT IS A NEW STEP IN THE REFORM OF IDEOLOGICAL AND POLITICAL EDUCATION IN UNIVERSITIES}

Ideological and political course in colleges and universities is an important position to consolidate the guiding position and adhere to the direction of socialist education of Marxism in the field of ideology in colleges and universities. It is the core curriculum for educating and helping young students to establish a correct world view, view of life and value. Exploring the ideological and political teaching reforms that really catch students' attention has always been a topic for all ideological educators.

\section{A. The Classroom Reform Movement Provides a Comprehensive Operational Space for the Integration of Big Data in Ideological and Political Education in Universities}

Since the word "big data" was proposed by NASA researchers in the 1990s, along with the rapid increase in the number of social network users, it has gradually been promoted to the level of national development strategy by China, the United States and other countries. Subsequently, for the burgeoning application and exploration of big data in the field of education, the Ministry of Education promulgated "Work Key Points for Education Informatization in 2016". It began to involve the field of ideological and political education, and followed the development process of "big data - application of big data - combination of big data with ideological and political education. As a kind of core competitiveness, big data has extremely powerful influence on "young people growing up together with the Internet." In order to achieve effective ideological and political education for such groups, we must grasp the characteristics of the times, adapt to big data, integrate big data, and improve educational teaching methods. Only by this way can we guide young students' ideas well and achieve education teaching.

The classroom reform movement is a product of educational informatization and it provides a comprehensive operational space for the integration of big data in ideological and political education in universities. On the one hand, the use of big data technology and information resources can increase the flexibility of the ideological and political education teaching model, achieve personalized education, integrate the predictability of big data, conduct timely judgments on students' behaviors, and dynamically capture effective information of students such as learning ability, interest, personality, etc.. It makes it possible that implementing more targeted ideological and political teaching on the basis of timely information resources. On the other hand, the upgraded classrooms have found a terrific foothold for big data. It can help teachers apply modern information technology in the classroom fully and increase positive interaction with students. In class, teachers can demonstrate teaching activities while demonstrating knowledge courseware. The activities process and results that students participate in can be displayed through different large screens at the same time. It solves the major problem of how to achieve two-way interaction in education informatization completely. In addition, timely feedback of classroom effect information forms big data resources, which provides information resources for ongoing classroom teaching and future ideological and political education effectively forms a positive relationship between big data information resources and ideological and political education.

\section{B. The Classroom Reform Movement Provides a Place for "Middle-class Teaching and Small-class Discussion" in the Ideological and Political Education in Universities}

In August 2015, the Propaganda Department of the Central Committee of the CPC and the Ministry of Education jointly issued the "Innovation Plan for the Construction of Ideological and Political Theory Courses in Colleges and Universities" (referred to as the "Innovation Plan") in order to comprehensively promote comprehensive reform and innovation in ideological and political theory courses in universities. According to the requirements of "Innovation Plan": teaching scale should be set reasonably, the the middle-class teaching should be implemented; the class size in principle should not exceed 100 people. The modern technologies such as the Internet should be made full use to explore the teaching modes of mid-class class and smallclass seminar. However, the current awkward circumstance is universal existence of "Lectures of one hundred people", "teachers' Monologue", "Students being phubber", "no communication between teachers and students", which caused less guaranteed teaching effect. One of the reasons for the embarrassing situation is the shortage of classroom resources in colleges and universities, ideological and political classes are often "pushed aside" to large amphitheatre classrooms; in addition to the shortage of classrooms, there is no suitable small class for discussion is the key to the problem. If teaching is conducted in accordance with the ideological and political teaching model of "middle-class teaching and small-class seminar", it is bound to carry out multi-level teaching arrangements for the teaching class and divide middle class into several small classes. At the same time, in order to achieve good teaching results, when classifying small classes, the factors such as students' grades, majors, and gender should be considered. The most critical link is the classroom arrangement.

The outputs of the classroom reform movement are perfect places for the implementation of "small-class seminar". First, the flexible combination of tables and chairs is beneficial for students to gather into groups and discuss together. Secondly, the platform in the same plane with desks and chairs objectively reduces the authority of teachers and breaks the normal form of teacher-centered. It fully embodies teachers' roles transformation from teachers of knowledge to instructors, as well as supporters and servers of learning, and realizes equality between teachers and students in the real sense. It is also conducive to narrowing the distance between teachers and students and creating a relaxed and active learning atmosphere. Thirdly, advanced information technology and screens can realize two-way interaction, intercommunication of multiple terminals, and solve the problem of "phubber" completely. It can also display students' learning results timely and reflect the 
correct mode of visualizing big data. Of course, based on the reform of scene-based education, it is costly and it is very difficult to convince the school to carry out the reform comprehensively.

\section{The Classroom Reform Movement Provids Technical Support for the Collaborative Application of Micro- curricular and Case Teaching in Ideological and Political Education in Universities}

The tide of MOOC has made the construction of microcurriculums, MOOC, and online courses become the "treasure" for many colleges and universities to crack down on educational difficulties. However, after spending huge sums of money to vigorously promote the construction of curriculum resources, the effect is not satisfactory. The Ministry of Education established 2017 as the "Year of Ideological and Political Education Quality in Colleges and Universities" and formulated the "2017 Overall Plan for Teaching Quality of Ideological and Political Theory Courses in Colleges and Universities", stating that "focus should be placed on classroom teaching, practical teaching, and online teaching to develop teaching methods, and guiding universities and colleges to continuously enhance the interactive, participatory, and vitality of ideological and political teaching." The ideological and political course has the characteristics of theory and practice. In the teaching process, it should not only pay attention to the theoretic guidance of students, but also focus on the cultivation of students' actions and practice. Because of its characteristics of vividness, typicality, interactivity, and authenticity, case teaching has been widely used in the course of ideological and political teaching. The characteristics of the vividness, refinement, space, and timeliness of micro lessons combine the two to explore a new type of teaching method and model, which embodies the superiority of conforming to the trend of ideological and political education and teaching reform and adapting to teaching information innovation.

At the same time, the coordinated application of microcurriculum and case teaching avoids the long teaching of class knowledge and cases, but shows in short and refined form, which is easily welcomed by students. The classroom reform movement can be said to provide maximum technical support for the collaborative application of micro-curriculum and case teaching in ideological and political education in universities. Young students in colleges and universities all are original inhabitants of the Internet. They are keen and accustomed to the use of modern media and communication tools. This is one of the important reasons that "phubber" are common in colleges and universities. With the help of simultaneous display and interaction using multi-screen or circular screens in upgrading classrooms, the integration of micro-class and case teaching is more in line with the behavior of young students. The micro-courses, cases, and student discussion are displayed on different screens under the control of teachers. Flexible interaction based on the needs of teaching progress, process, and content can effectively get rid of the boring dilemma of ideological teaching, improve the attraction of ideological and political course, improve students' attention on the teaching and the effectiveness of ideological and political teaching.

\section{CONCLUSION}

The classroom reform movement means that the traditional teaching model of academism has started to collapse, and the revolution in teaching ideas has been started with the change of teaching scenes. With the main reform directions of integrating big data information resources and opening up small-classes seminar and collaborative application of micro-course and case teaching, the teaching reform of college ideological and political education courses should seize this opportunity to truly establish the "student-centered" teaching model and equal status of "double subjects of teaching and learning", and make students "move" and "live" in the ideological and political classroom.

\section{REFERENCES}

[1] Jiao Jianli. Learning Space and Its Development Tendency [J]. China Information Technology Education, 2016 (17). 焦建利. 学习空间极 其发展趋势[J].中国信息技术教育,2016(17).

[2] Lei Zhaozi. Educational Informatization: From 1.0 to 2.0 - The Development and Thinking of China's Educational Informatization in the New Era $[\mathrm{J}]$. Journal of East China Normal University (Educational Sciences), 2018(1). 雷朝滋.教育信息化:从 1.0 走向 2.0 一 新时代我国教育信息化发展的走向与思路 $[\mathrm{J}]$. 华东师范大学 学报(教育科学版), 2018(1).

[3] Ren Youqun et al. Integrating Innovation, Smart Leading, and Embracing the New Era of Educational Information [J]. China Educational Technology, 2018(1). 任友群等.融合创新, 智能引 领, 迎接教育信息化新时代[J].中国电化教育,2018(1).

[4] Mao Jing. Prof. The two trends that Lu Xiaodong, deputy minister of the Department of Education in Peking University, came to our school to talk about the teaching reform of universities - The new engineering and small-class seminar [EB/OL] http://xww.bucea.edu.cn/ Tgx/103732.htm,2017-05-24. 毛静.北京大 学教务部副部长卢晓东教授来我校畅谈高校教学改革的两个趋势 - 新工 科和小班研讨课 [EB/OL]http://xww.bucea.edu.cn/tgx/103732.htm,2017-05-24.

[5] Chen Wuyong et al. The Teaching Mode of "Teaching in Large Classes - Small Class Discussion" in the Course Teaching of Tanning Chemistry [J]. Leather Science and Engineering, 2015(2). 陈武勇等.” 大班授课-小班讨论”教学模式在鞣制化学课程教学中的实践 $[\mathrm{J}]$.皮 革科学与工程,2015(2). 